
\title{
28 Research Soure \\ Effect of Dissolve Organic Matter Nn Cd Contaminated Cotton (Gossypium Hirsutum L.) Growth and Cd Uptake
}

\section{Tao Min}

Shihezi University College of Agriculture https://orcid.org/0000-0001-7593-1510

\section{Tong Luo}

Shihezi University College of Agriculture

\section{Lili Chen}

Shihezi University College of Agriculture

\section{Yan Wang}

Shihezi University College of Agriculture

\section{Liyang Cheng}

Shihezi University College of Agriculture

\section{Ru Sibo}

Shihezi University College of Agriculture

Junhua Li ( $\nabla$ ljh630703@163.com )

Shihezi University College of Agriculture

\section{Weidan Lu}

Shihezi University College of Agriculture

\section{Research Article}

Keywords: Dissolved organic matter, Cadmium, Antioxidant system, Cotton, Photosysthesis

Posted Date: June 22nd, 2021

DOI: https://doi.org/10.21203/rs.3.rs-510150/v1

License: (c) (1) This work is licensed under a Creative Commons Attribution 4.0 International License. Read Full License 


\section{Abstract}

In this study, we investigated the effects of originating from cotton straw dissolved organic matter (CM) and farmyard manure dissolved organic matter (FM) on the physiological growth and Cd uptake and transport of cotton under two exogenous $C d$ addition gradients $\left(5 \mathrm{mg} \cdot \mathrm{kg}^{-1}\right.$ and $10 \mathrm{mg} \cdot \mathrm{kg}^{-1} ; 0 \mathrm{mg} \cdot \mathrm{kg}^{-1}$ as control) by pot experiments, and characterized the structures of CM and FM by UV-Visible spectroscopy. The results showed that $\mathrm{CM}$ had more low aromatic and low molecular weight hydrophibic fulvic acid fractions than FM. Cd stress reduced the total biomass (especially the lints), leaf photosynthetic intensity and SPAD value, increased the $C d$ content and transport coefficient in all parts of cotton, and stimulated the oxidative stress response in leaves. At low Cd levels (no exogenous Cd addition), application of DOM promoted cotton growth and increased leaf photosynthetic intensity and SPAD values; at medium to high Cd levels ( $5 \mathrm{mg} \cdot \mathrm{kg}^{-1}$ and $10 \mathrm{mg} \cdot \mathrm{kg}^{-1}$ exgenous Cd addition), application of DOM exhibited inhibitory effects on cotton growth (as shown by reduced leaf photosynthetic capacity, altered membrane antioxidant regulation) and changed Cd content in various parts of cotton. In addition, the inhibitory effect of $\mathrm{CM}$ on cotton growth and the ability to change $\mathrm{Cd}$ content in all parts was greater than that of FM. The redundancy analysis showed that the effect of DOM addition on cotton growth changed from promotion to inhibition when the level of exogenous Cd contamination reached $5 \mathrm{mg} \cdot \mathrm{kg}^{-1}$. Therefore, both straw return and farmyard manure application (especially straw return) in agricultural fields with high Cd contamination levels ( $\geq 5 \mathrm{mg} \cdot \mathrm{kg}^{-1}$ ) can be harmful to cotton physiological growth and pose a threat to cotton production.

\section{Introduction}

Soil heavy metal pollution is a global problem that causes food yield reduction and economic loss every year, especially soil cadmium pollution (Meers et al. 2010). In China, more than 13 million hectares of cropland are contaminated with cadmium (Hu et al. 2016), which has a high mobility and bioavailability, so it is easily absorbed by plants (Mwilola et al. 2020). Cadmium is a non-essential element for plants. Under normal circumstances, most of cadmium is stored in the roots system of plant, while the remaining part is transported through the xylem to the aboveground part of the plant and redistributed in various aboveground organs, eventually leading to heavy metal stress symptoms in plants, such as yellowing of plant leaves, plant dwarfism and reduced biomass (Ouariti et al. 1997; Akhter et al. 2014; John 1973). In addition, $\mathrm{Cd}$ causes impaired chloroplast synthesis, reduced photosynthetic rate, and disruption of intracellular antioxidant systems in plants (Yang et al. 2020; An et al. 2019; Liu et al. 2021).

Dissolved organic matter (DOM) is one of the most active components of organic matter, which has a beneficial effect on the growth of plants (Trevisan et al. 2010). It mainly originates from roots secretions and decomposed plant and animal bodies (Hubova et al. 2017), but measures such as straw return and farmyard manure application in agroecosystems can bring in large amounts of DOM (Gondek et al. 2018; Huang et al. 2019). The DOM is rich in a variety of organic components with different molecular weights and negatively charged functional groups (Shan et al. 2019), which can change the soil physicochemical 
properties when it enters the soil (Mei et al. 2020) and affect the behavior of soil adsorption, desorption and complexation of Cd (Zhou et al. 2017; Yuan et al. 2015), which in turn affects the morphology, transformation, migration and bioeffectiveness of Cd (Pan and Zhou 2007; Lu et al 2020), ultimately causes changes in the $\mathrm{Cd}$ content in plants, resulting in changes in plant growth. Previous studies found that DOM inputs increased the water-soluble Cd content and improved the effectiveness of soil $\mathrm{Cd}(\mathrm{Xu}$ and Yuan 2009), as well as the migration and biological effectiveness of $\mathrm{Cd}$ at different levels of $\mathrm{Cd}$ contamination (Wang et al. 2020).

Xinjiang as the main cotton producing region in China. According to the National Bureau of Statistics, the planted area and production of cotton in Xinjiang has reached $3,169,900 \mathrm{hm}^{2}$ and $5,910,000$ tons by 2020. However, excessive application of chemical fertilizers and pesticides and irrational industrial activities inevitably increase the content of heavy metals in the soil (Liu et al. 2021; Ran et al. 2021) making cotton growth affected. Meanwhile, a large amount of cotton straw resources and farmyard manure resources are put into the farmland every year to improve the resource utilization of agricultural waste and reduce chemical fertilizer application (Zhang et al. 2021), but the effects of DOM produced by straw and farmyard manure on cotton growth and $\mathrm{Cd}$ uptake often differences on soils with different degrees of Cd contamination.

Therefore, DOM extracted from cotton straw and farmyard manure was chosen for this experiment to analyze the effects of DOM produced by straw return and farmyard manure application on cotton growth and Cd uptake transfer on Cd-contaminated soils through pot experiments. The main objectives of this work were to investigate 1) the effect of different soil Cd contamination levels on cotton growth, 2) the extent of the effect of DOM addition on cotton growth in Cd-contaminated soil, and 3) the difference in Cd content of cotton in Cd-contaminated soil by DOM addition. Our study provides a basis for evaluating the effect of DOM on cotton growth under Cd contamination and the use of agricultural waste.

\section{Materials And Methods}

\section{Experimental materials}

The soil samples obtained in this experiment were collected from the surface soil $(0-20 \mathrm{~cm})$ of the Text Station of Agricultural College, Shihezi University. The soil pH was 8.10, organic matter content was 9.37 $\mathrm{g} \cdot \mathrm{kg}^{-1}$, alkali hydrolyzable $\mathrm{N}$ was content $55.88 \mathrm{mg} \cdot \mathrm{kg}^{-1}$, available $\mathrm{P}$ content was $26.82 \mathrm{mg} \cdot \mathrm{kg}^{-1}$, available $\mathrm{K}$ content was $165.41 \mathrm{mg} \cdot \mathrm{kg}^{-1}$. The soil of content of $\mathrm{Cd}$ was $0.69 \mathrm{mg} \cdot \mathrm{kg}^{-1}$.

\section{DOM extraction from different sources}

For the DOM, fresh cotton stalk samples and farmyard manure samples were collected from College of Agricultural and the College of Animal Science and Technology of Shihezi University. The materials were air-dried, pulverized, and put into a conical flasks with deionized water at a material to water weight ratio of $1: 10$. All samples were shaken at $220 \mathrm{rpm}$ for $18 \mathrm{~h}$ at $25 \pm 1^{\circ} \mathrm{C}$. After centrifugation at $12000 \mathrm{rpm}$ for 
$10 \mathrm{~min}$, the supernatants were filtered though a $0.45-\mu \mathrm{m}$ membrane filter. The filtrates were stored at $4^{\circ} \mathrm{C}$ until use. The basic properties of DOM are shown in Table 1.

Table 1

Basic properties of the exogenous DOM

\begin{tabular}{|lcllllll|}
\hline DOM Sources & pH & $\begin{array}{l}\text { DOC } \\
\left(\mathbf{m g} \cdot \mathrm{L}^{-1}\right)\end{array}$ & $\begin{array}{l}\text { Cd } \\
\left(\mathbf{m g} \cdot \mathbf{k g}^{-1}\right)\end{array}$ & SUVA254 & SUVA260 & SUVA280 & A250/A365 \\
\hline CM & 4.89 & 250 & 0.02 & 1.88 & 1.79 & 1.58 & 4.7 \\
\hline FM & 8.51 & 250 & 0.01 & 2.11 & 2.03 & 1.82 & 3.13 \\
\hline CM = cotton straw DOM, FM = farmyard manure DOM. & & & \\
\hline
\end{tabular}

\section{Preparation of contaminated soil}

Different concentrations of exogenous cadmium in the form of $\mathrm{CdCl}_{2} \cdot 2.5 \mathrm{H}_{2} \mathrm{O}$ solution were exgenous added to the soil at $0 \mathrm{mg} \cdot \mathrm{kg}^{-1}, 5 \mathrm{mg} \cdot \mathrm{kg}^{-1}$ and $10 \mathrm{mg} \cdot \mathrm{kg}^{-1}$, respectively, and mixed thoroughly with the soil. The contaminated soil as preserved for 30 days for subsquent used.

\section{Experimental design}

In this study, cotton (Xinluzao 84) was used as the subject of study, and then each pot was weight with $6.0 \mathrm{~kg}$ of dry soil sieved through $5 \mathrm{~mm}$ in a plastic pot $(20 \mathrm{~cm}$ in diameter and $25 \mathrm{~cm}$ in high). The soil in each pot was fertilized manually with urea, diammonium phosphate and potassium sulfate at the does of $0.2 \mathrm{~g} \cdot \mathrm{kg}^{-1} \mathrm{~N}, 0.2 \mathrm{~g} \cdot \mathrm{kg}^{-1} \mathrm{P}_{2} \mathrm{O}_{5}$, and $0.2 \mathrm{~g} \cdot \mathrm{kg}^{-1} \mathrm{~K}_{2} \mathrm{O}$, respectively.

A total of nine treatments, including two treatments with addition of DOM [ CM (cotton stalk DOM) and FM (farmyard manure DOM), CK (deionized water)], and three treatments with addition of Cd [CO (0 $\left.\mathrm{mg} \cdot \mathrm{kg}^{-1}\right), \mathrm{C} 5\left(5 \mathrm{mg} \cdot \mathrm{kg}^{-1}\right)$ and C10 $\left.\left(10 \mathrm{mg} \cdot \mathrm{kg}^{-1}\right)\right]$, with four repetitons per treatment. For the DOM, diluted with water to a concentration of $250 \mathrm{mg} \cdot \mathrm{L}^{-1}$ according to DOC content, and $120 \mathrm{~mL}$ was applied per pot. A total of nine applications were made in 10 days application cycle during the growth period. Plant samples were harvested at the cotton defoliation stage.

\section{Determination of UV-visible spectral characteristic parameters}

The absorption spectra of DOM were measured by UV-visible spectrophotometer scanned with a $10 \mathrm{~mm}$ quartz cuvette in the wavelength range of $200-700 \mathrm{~nm}$ with an interval of $2 \mathrm{~nm}$. The absorption coefficients were calculated based on the equation $a(\lambda)=2.303 \times A / I$ and SUVA $A_{\lambda}=a(\lambda) / D O C$, using the absorbance values at $250 \mathrm{~nm}, 254 \mathrm{~nm}, 260 \mathrm{~nm}, 280 \mathrm{~nm}$ and $365 \mathrm{~nm}$ as A, respectivel (Ni et al. 2017). Where $\lambda$ is the wavelength $(\mathrm{nm}), \mathrm{a}(\lambda)$ is the absorption coefficient at wavelength $\lambda\left(\mathrm{m}^{-1}\right)$, and $\mathrm{I}$ is the light path $(m)$.

\section{Determination of biomass}


After harvesting, the cotton was washed with deionized water and divided into roots, stems, leaves, shells, lints and seeds parts. The plant parts were deactivated in an oven at $105^{\circ} \mathrm{C}$ for $30 \mathrm{~min}$, then baked at $75^{\circ} \mathrm{C}$ until constant weight and weighed on a one-percent balance. The powders were crushed and tested.

\section{Determination of antioxidant enzymes and lipid peroxidation in leaves}

Spectrophotometric method for determination of antioxidant enzymes and lipid peroxidation. Leaves samples superoxide dismutase (SOD) activity was determined by photochemical reduction of NBT. The peroxidase (POD) activity was determined by guaiacol method. The catalase (CAT) activity was determined by hydrogen peroxide decomposition method. The content of malondialdehyde (MDA) was determined by thiobarbituric acid reactive substances (TBARS) (An et al. 2019).

\section{Determination of SPAD and photosynthetic characteristics}

The leaves chlorophyll content was determined by SPAD-502 (USA) chlorophyll meter. Net photosynthetic rate $(\mathrm{Pn})$, stomatal conductance $(\mathrm{Gs})$, transpiration rate $(\mathrm{Tr})$, and intracellular $\mathrm{CO}_{2}$ concentration (Ci) were determined with a portable photosynthesis system LI-6800 (LI-COR, Lincoln, USA).

\section{Determination of Cd content and transport coefficient in different parts in cotton}

The concertration of $\mathrm{Cd}$ content in the cotton samples $(0.1000 \mathrm{~g})$ were digested with $3 \mathrm{~mL} \mathrm{HCl}$ and $5 \mathrm{~mL}$ $\mathrm{HNO}_{3}$, then using a microwave digestion system (CEM-Mars 6, USA) to accelerate this reaction. After filtration of suspensions, shaked and diluted into $50 \mathrm{~mL}$, using ICAP 6300 (Thermo Fisher, USA) to determinate.

The formula for the transport coefficient is as follows:

$\mathrm{TF}_{\text {Roots }}-$ Stems $=$ Stems Cd / Roots Cd

$\mathrm{TF}_{\text {Stems }}-$ Leaves $=$ Leaves Cd / Stems Cd

$\mathrm{TF}_{\text {Stems- }}$ Shells $=$ Shells Cd / Stems Cd

$\mathrm{TF}_{\text {Stems- lints }}=$ lints Cd / Stems Cd

$\mathrm{TF}_{\text {Stems- Seeds }}=$ Seeds $\mathrm{Cd} /$ Stems Cd

\section{Statistical analysis}

The data were analyzed in statistics using SPSS 21.0. To compare between different treatments using Duncan's new multiple range test $(a=0.05)$. The charts were made using Origin $2019 \mathrm{~b}$ and Rstudio 4.0.3. 


\section{UV-visible spectral characteristic analysis of DOM}

On the previous studies shown that SUVA254, SUVA260 and SUVA280 can be used to characterize DOM aromaticity, hydrophobicity and molecular weight, and their values are proportional to the degree of aromatization, hydrophobic component and molecular weight size (Chang et al. 2017). The ultraviolet parameter A250/A365 is the absorbance value of DOM at $250 \mathrm{~nm}$ and $365 \mathrm{~nm}$, which is used to characterize the degree of humification of DOM, and a ratio greater than 3.5 indicates that the fulvic acid content of DOM is greater than the huminic acid content (Xie et al. 2013). As shown in Table 1, the CM values of SUVA254, SUVA260 and SUVA280 are smaller than FM, indicating that CM has lower aromaticity, hydrophibicity and molecular weight compared to FM. And the UV parameter A250/A365 indicates that there are more fulvic acid components in CM.

\section{The effect of DOM on cotton growth}

With an increase of exogenous $\mathrm{Cd}$ addition, the biomass of cotton decreased (Table 2). The total biomass of cotton in the C5CK treatment and C10CK treatment decreased by $5.04 \%$ and $12.87 \%$, respectively, compared with those the COCK treatment. After the application of DOM, the biomass of cotton has been changed. Compared with COCK treatment, COCM and COFM treatments increased the total biomass of cotton of $3.14 \%$ and $8.46 \%$, respectively. In addition, the shells and roots biomass are significantly higher than for COCK treatments. Compared with C5CK treatments, C5CM and C5FM treatments had negative effects on the cotton biomass accumulation (Except for roots biomass), and the inhibit ability of CM is higher than FM. When the content of heavy metal added was $10 \mathrm{mg} \cdot \mathrm{kg}^{-1}$, the effect of DOM on the biomass of cotton had a same trend. 
Table 2

The effect of DOM on the biomass of different parts of the cotton.

\begin{tabular}{|c|c|c|c|c|c|c|c|}
\hline Treatments & $\begin{array}{l}\text { Roots } \\
\left(\mathrm{g} \cdot \operatorname{pot}^{-1}\right)\end{array}$ & $\begin{array}{l}\text { Stems } \\
\left(\mathrm{g} \cdot \operatorname{pot}^{-1}\right)\end{array}$ & $\begin{array}{l}\text { Leaves } \\
\left(\mathrm{g} \cdot \operatorname{pot}^{-1}\right)\end{array}$ & $\begin{array}{l}\text { Shells } \\
\left(\mathrm{g} \cdot \operatorname{pot}^{-1}\right)\end{array}$ & $\begin{array}{l}\text { Fints } \\
\left(\mathrm{g} \cdot \operatorname{pot}^{-1}\right)\end{array}$ & $\begin{array}{l}\text { Seeds } \\
\text { (g.pot } \\
\left.{ }^{1}\right)\end{array}$ & $\begin{array}{l}\text { Total } \\
\text { Biomass } \\
\left(\mathrm{g} \cdot \mathrm{pot}^{-1}\right)\end{array}$ \\
\hline COCK & $\begin{array}{l}4.53 \pm \\
0.23 b\end{array}$ & $\begin{array}{l}18.13 \pm \\
2.06 a\end{array}$ & $\begin{array}{l}12.35 \pm \\
0.40 a\end{array}$ & $\begin{array}{l}12.61 \pm \\
0.23 b\end{array}$ & $\begin{array}{l}2.26 \pm \\
0.35 a\end{array}$ & $\begin{array}{l}2.73 \pm \\
0.18 a\end{array}$ & $\begin{array}{l}52.61 \pm \\
0.59 b\end{array}$ \\
\hline COCM & $\begin{array}{l}4.77 \pm \\
0.46 \mathrm{ab}\end{array}$ & $\begin{array}{l}18.82 \pm \\
2.52 a\end{array}$ & $\begin{array}{l}12.17 \pm \\
0.92 a\end{array}$ & $\begin{array}{l}13.68 \pm \\
0.47 a \mathrm{a}\end{array}$ & $\begin{array}{l}1.87 \pm \\
0.06 a\end{array}$ & $\begin{array}{l}2.94 \pm \\
0.06 a\end{array}$ & $\begin{array}{l}54.26 \pm \\
2.41 \mathrm{ab}\end{array}$ \\
\hline COFM & $\begin{array}{l}5.44 \pm \\
0.39 a\end{array}$ & $\begin{array}{l}19.37 \pm \\
1.31 \mathrm{a}\end{array}$ & $\begin{array}{l}12.86 \pm \\
1.10 \mathrm{a}\end{array}$ & $\begin{array}{l}14.32 \pm \\
0.49 a\end{array}$ & $\begin{array}{l}1.98 \pm \\
0.22 \mathrm{a}\end{array}$ & $\begin{array}{l}3.10 \pm \\
0.33 a\end{array}$ & $\begin{array}{l}57.06 \pm \\
1.94 a\end{array}$ \\
\hline C5CK & $\begin{array}{l}3.93 \pm \\
0.35 b\end{array}$ & $\begin{array}{l}18.23 \pm \\
0.45 a\end{array}$ & $\begin{array}{l}12.22 \pm \\
0.85 a\end{array}$ & $\begin{array}{l}11.44 \pm \\
1.17 a\end{array}$ & $\begin{array}{l}1.71 \pm \\
0.09 \mathrm{ab}\end{array}$ & $\begin{array}{l}2.43 \pm \\
0.15 b\end{array}$ & $\begin{array}{l}49.96 \pm \\
1.22 a\end{array}$ \\
\hline C5CM & $\begin{array}{l}4.82 \pm \\
0.34 a\end{array}$ & $\begin{array}{l}16.31 \pm \\
2.50 \mathrm{a}\end{array}$ & $\begin{array}{l}8.66 \pm \\
0.82 b\end{array}$ & $\begin{array}{l}12.39 \pm \\
0.75 a\end{array}$ & $\begin{array}{l}1.51 \pm \\
0.05 b\end{array}$ & $\begin{array}{l}2.33 \pm \\
0.11 b\end{array}$ & $\begin{array}{l}46.03 \pm \\
1.18 \mathrm{~b}\end{array}$ \\
\hline C5FM & $\begin{array}{l}4.61 \pm \\
0.17 a\end{array}$ & $\begin{array}{l}16.07 \pm \\
0.88 a\end{array}$ & $\begin{array}{l}11.14 \pm \\
1.07 a\end{array}$ & $\begin{array}{l}11.12 \pm \\
1.66 a\end{array}$ & $\begin{array}{l}1.82 \pm \\
0.14 a\end{array}$ & $\begin{array}{l}2.83 \pm \\
0.22 a\end{array}$ & $\begin{array}{l}47.59 \pm \\
1.24 a b\end{array}$ \\
\hline C10CK & $\begin{array}{l}3.29 \pm \\
0.16 b\end{array}$ & $\begin{array}{l}18.43 \pm \\
1.34 a\end{array}$ & $\begin{array}{l}9.09 \pm \\
0.11 \mathrm{ab}\end{array}$ & $\begin{array}{l}11.10 \pm \\
1.23 a\end{array}$ & $\begin{array}{l}1.61 \pm \\
0.13 a\end{array}$ & $\begin{array}{l}2.32 \pm \\
0.25 a\end{array}$ & $\begin{array}{l}45.84 \pm \\
1.65 a\end{array}$ \\
\hline C10CM & $\begin{array}{l}3.98 \pm \\
0.23 a\end{array}$ & $\begin{array}{l}14.21 \pm \\
2.03 \mathrm{~b}\end{array}$ & $\begin{array}{l}8.36 \pm \\
0.68 \mathrm{~b}\end{array}$ & $\begin{array}{l}11.90 \pm \\
0.78 a\end{array}$ & $\begin{array}{l}1.49 \pm \\
0.18 a\end{array}$ & $\begin{array}{l}2.03 \pm \\
0.19 a\end{array}$ & $\begin{array}{l}41.97 \pm \\
2.58 \mathrm{~b}\end{array}$ \\
\hline C10FM & $\begin{array}{l}4.29 \pm \\
0.22 \mathrm{a}\end{array}$ & $\begin{array}{l}17.52 \pm \\
0.82 \mathrm{a}\end{array}$ & $\begin{array}{l}9.42 \pm \\
0.34 a\end{array}$ & $\begin{array}{l}11.22 \pm \\
0.86 a\end{array}$ & $\begin{array}{l}1.58 \pm \\
0.19 a\end{array}$ & $\begin{array}{l}2.26 \pm \\
0.25 a\end{array}$ & $\begin{array}{l}46.29 \pm \\
0.66 a\end{array}$ \\
\hline
\end{tabular}

\section{The effect of DOM on photosynthesis and SPAD of cotton}

Supply of exogenous $\mathrm{Cd}$ to the plants had an adverse impact on the photosynthesis and SPAD values (Table 3). Compared with COCK treatments, the net photosynthetic, leaves stomatal conductance, transpiration rate and SPAD values are reduced in the C5CK and C10CK treatments, but the intercellular $\mathrm{CO}_{2}$ concentration are gradually increased. Application of DOM at the $\mathrm{CO}$ level promoted leaves net photosynthetic rate and SPAD values, but there was no significant difference between the $\mathrm{CM}$ and $\mathrm{FM}$ treatments. Compared to $\mathrm{C} 5 \mathrm{CK}, \mathrm{C} 5 \mathrm{CM}$ and C5FM significantly reduced leaves net photosynthetic rate (20.56\% and $17.77 \%)$ and SPAD values (13.22\% and $8.36 \%$ ), and leaves intercellular $\mathrm{CO}_{2}$ concentration was increased to different degrees. C10CK and C10CM and C10FM showed the same trend, with the CM treatment having a stronger effect on photosynthetic parameters and SPAD values than the FM treatment. 
Table 3

The effect of DOM on photosynathesis and SPAD of cotton

\begin{tabular}{|c|c|c|c|c|c|}
\hline Treatments & $\begin{array}{l}\mathrm{Pn} \\
\left(\mu \mathrm{mol} \cdot \mathrm{m}^{-2} \cdot \mathrm{s}^{-}\right. \\
\left.{ }^{1}\right)\end{array}$ & $\begin{array}{l}\text { Gs } \\
\left(\mathrm{mmol} \cdot \mathrm{m}^{-2} \cdot \mathrm{s}^{-}\right. \\
\left.{ }^{1}\right)\end{array}$ & $\begin{array}{l}\mathrm{Ci} \\
\left(\mu \mathrm{mol} \cdot \mathrm{mol}^{-1}\right)\end{array}$ & $\begin{array}{l}\text { Tr } \\
\left(\mathrm{mmol} \cdot \mathrm{m}^{-2} \cdot \mathrm{s}^{-}\right. \\
\left.{ }^{1}\right)\end{array}$ & SPAD \\
\hline COCK & $3.98 \pm 0.24 b$ & $129.63 \pm 7.37 a$ & $\begin{array}{l}311.04 \pm \\
12.05 a\end{array}$ & $3.33 \pm 0.27 a$ & $39.04 \pm 1.34 b$ \\
\hline $\mathrm{COCM}$ & $4.75 \pm 0.21 a$ & $\begin{array}{l}132.74 \pm \\
13.22 \mathrm{a}\end{array}$ & $\begin{array}{l}303.91 \pm \\
12.46 a\end{array}$ & $3.74 \pm 0.37 a$ & $41.18 \pm 1.14 a$ \\
\hline COFM & $4.31 \pm 0.43 a b$ & $123.15 \pm 5.61 a$ & $307.73 \pm 7.02 a$ & $3.65 \pm 0.38 a$ & $\begin{array}{l}40.52 \pm \\
1.47 a b\end{array}$ \\
\hline C5CK & $3.94 \pm 0.12 a$ & $116.29 \pm 5.39 a$ & $\begin{array}{l}324.50 \pm \\
13.89 b\end{array}$ & $2.72 \pm 0.23 a$ & $35.40 \pm 1.62 a$ \\
\hline $\mathrm{C} 5 \mathrm{CM}$ & $3.13 \pm 0.17 b$ & $106.64 \pm 9.29 a$ & $\begin{array}{l}357.79 \pm \\
13.85 a\end{array}$ & $2.42 \pm 0.34 a$ & $30.72 \pm 2.27 b$ \\
\hline C5FM & $3.24 \pm 0.45 b$ & $104.18 \pm 9.77 a$ & $\begin{array}{l}343.81 \pm \\
9.52 \mathrm{ab}\end{array}$ & $2.49 \pm 0.48 a$ & $32.44 \pm 0.96 b$ \\
\hline C10CK & $3.14 \pm 0.37 a$ & $109.70 \pm 6.40 a$ & $341.94 \pm 5.88 b$ & $2.44 \pm 0.20 \mathrm{a}$ & $31.90 \pm 3.78 a$ \\
\hline C10CM & $2.31 \pm 0.12 b$ & $98.92 \pm 5.02 a$ & $\begin{array}{l}360.50 \pm \\
12.86 a\end{array}$ & $2.04 \pm 0.09 b$ & $27.26 \pm 1.72 b$ \\
\hline C10FM & $2.41 \pm 0.14 b$ & $101.54 \pm 9.55 a$ & $\begin{array}{l}343.71 \pm \\
11.10 \mathrm{~b}\end{array}$ & $2.39 \pm 0.24 a$ & $\begin{array}{l}28.48 \pm \\
2.94 a b\end{array}$ \\
\hline
\end{tabular}

Datas are means \pm standard deviation. Different small letters indicate significant differences at $P<0.05$. $\mathrm{CK}=$ deionized water, $\mathrm{CM}=$ cotton straw $\mathrm{DOM}, \mathrm{FM}=$ farmyard manure $\mathrm{DOM} ; \mathrm{CO}=$ no exgenous $\mathrm{Cd}$ addition, $\mathrm{C} 5=5 \mathrm{mg} \cdot \mathrm{kg}^{-1}$ exgenous $\mathrm{Cd}$ addition, $\mathrm{C} 10=10 \mathrm{mg} \cdot \mathrm{kg}^{-1}$ exgenous $\mathrm{Cd}$ addition .

\section{The effect of DOM on activities of antioxidant enzymes and MDA content of cotton leaves}

The strength of leaves antioxidant enzymes and MDA activity changes with the level of exogenous Cd addition to produce a corresponding oxidative stress response (Fig. 1). Compared to COCK, MDA and CAT activities of C5CK and C10CK leaves increased with increasing exogenous Cd concentration, while SOD and POD activities decreased with increasing exogenous Cd concentration. DOM application can alter antioxidant enzymes and MDA activity to some extent. Treatments with DOM applied at C5 and C10 levels further increased leaves MDA and CAT activity, while SOD activity was significantly reduced, compared with no DOM application. POD activity showed a decrease at the C10 level, but did not reach a significant difference at the $\mathrm{C} 5$ level.

\section{The effect of DOM on Cd content of cotton}


With increasing levels of exogenous $\mathrm{Cd}\left(0 \mathrm{mg} \cdot \mathrm{kg}^{-1}, 5 \mathrm{mg} \cdot \mathrm{kg}^{-1}, 10 \mathrm{mg} \cdot \mathrm{kg}^{-1}\right)$, the overall trend of $\mathrm{Cd}$ content in all parts of cotton increased, reaching a high level at $10 \mathrm{mg} \cdot \mathrm{kg}^{-1}$ of exogenous Cd (Table 4). At the $\mathrm{CO}$ level, the roots system had the highest $\mathrm{Cd}$ content, followed by the stems and leaves, while the $\mathrm{Cd}$ content of cotton shells, cotton lints and seeds remained at low levels. At C5 and C10 levels, the level of $\mathrm{Cd}$ content in different parts of each treatment showed roots $>$ leaves $>$ seeds $>$ shells $>$ stems $>$ lints.

Compared to the COCK treatment, there was no significant difference in Cd content between the COCM treatment and the COFM treatment, except for significant differences in roots and stems Cd content. Compared to C5CK, C5CM and C5FM cotton lints Cd content was reduced by $32.26 \%$ and $19.35 \%$ respectively, while the rest of the parts showed different degrees of increase in Cd content (except for $\mathrm{C} 5 \mathrm{CM}$ stems). Compared with $\mathrm{C} 10 \mathrm{CK}$, the $\mathrm{Cd}$ content of all parts of $\mathrm{C} 10 \mathrm{CM}$ reached significant difference, but the $\mathrm{Cd}$ content of the rest parts of C10FM did not reach significant difference, except for the roots $\mathrm{Cd}$ content, which was significantly higher than that of $\mathrm{C} 10 \mathrm{CK}$.

Table 4

The effect of DOM on Cd content of various parts of cotton.

\begin{tabular}{|c|c|c|c|c|c|c|}
\hline Treatments & $\begin{array}{l}\text { Roots } \\
\left(\mathrm{mg} \cdot \mathrm{kg}^{-1}\right)\end{array}$ & $\begin{array}{l}\text { Stems } \\
\left(\mathrm{mg} \cdot \mathrm{kg}^{-1}\right)\end{array}$ & $\begin{array}{l}\text { Leaves } \\
\left(\mathrm{mg} \cdot \mathrm{kg}^{-1}\right)\end{array}$ & $\begin{array}{l}\text { Shells } \\
\left(\mathrm{mg} \cdot \mathrm{kg}^{-1}\right)\end{array}$ & $\begin{array}{l}\text { Lints } \\
\left(\mathrm{mg} \cdot \mathrm{kg}^{-1}\right)\end{array}$ & $\begin{array}{l}\text { Seeds } \\
\left(\mathrm{mg} \cdot \mathrm{kg}^{-1}\right)\end{array}$ \\
\hline COCK & $\begin{array}{l}1.03 \pm \\
0.08 c\end{array}$ & $\begin{array}{l}0.26 \pm \\
0.03 \mathrm{~b}\end{array}$ & $\begin{array}{l}0.19 \pm \\
0.04 a\end{array}$ & $\begin{array}{l}0.06 \pm \\
0.00 \mathrm{a}\end{array}$ & $\begin{array}{l}0.07 \pm \\
0.01 \mathrm{a}\end{array}$ & $\begin{array}{l}0.10 \pm \\
0.01 \mathrm{a}\end{array}$ \\
\hline COCM & $\begin{array}{l}1.91 \pm \\
0.04 a\end{array}$ & $\begin{array}{l}0.74 \pm \\
0.07 a\end{array}$ & $\begin{array}{l}0.17 \pm \\
0.04 a\end{array}$ & $\begin{array}{l}0.07 \pm \\
0.01 \mathrm{a}\end{array}$ & $\begin{array}{l}0.09 \pm \\
0.01 a\end{array}$ & $\begin{array}{l}0.10 \pm \\
0.00 a\end{array}$ \\
\hline COFM & $\begin{array}{l}1.40 \pm \\
0.03 b\end{array}$ & $\begin{array}{l}0.66 \pm \\
0.09 a\end{array}$ & $\begin{array}{l}0.21 \pm \\
0.03 a\end{array}$ & $\begin{array}{l}0.06 \pm \\
0.00 \mathrm{a}\end{array}$ & $\begin{array}{l}0.07 \pm \\
0.01 \mathrm{a}\end{array}$ & $\begin{array}{l}0.10 \pm \\
0.00 a\end{array}$ \\
\hline C5CK & $\begin{array}{l}16.66 \pm \\
1.01 \mathrm{c}\end{array}$ & $\begin{array}{l}1.28 \pm \\
0.07 \mathrm{~b}\end{array}$ & $\begin{array}{l}2.57 \pm \\
0.69 \mathrm{~b}\end{array}$ & $\begin{array}{l}1.74 \pm \\
0.26 \mathrm{~b}\end{array}$ & $\begin{array}{l}1.24 \pm \\
0.29 a\end{array}$ & $\begin{array}{l}2.68 \pm \\
0.07 b\end{array}$ \\
\hline C5CM & $\begin{array}{l}27.22 \pm \\
1.47 a\end{array}$ & $\begin{array}{l}0.68 \pm \\
0.10 c\end{array}$ & $\begin{array}{l}3.65 \pm \\
0.59 a\end{array}$ & $\begin{array}{l}2.19 \pm \\
0.11 \mathrm{a}\end{array}$ & $\begin{array}{l}0.84 \pm \\
0.09 \mathrm{~b}\end{array}$ & $\begin{array}{l}3.07 \pm \\
0.19 a\end{array}$ \\
\hline C5FM & $\begin{array}{l}20.62 \pm \\
2.15 b\end{array}$ & $\begin{array}{l}1.62 \pm \\
0.08 a\end{array}$ & $\begin{array}{l}2.75 \pm \\
0.36 a b\end{array}$ & $\begin{array}{l}1.73 \pm \\
0.24 b\end{array}$ & $\begin{array}{l}0.97 \pm \\
0.16 a b\end{array}$ & $\begin{array}{l}2.72 \pm \\
0.35 a b\end{array}$ \\
\hline C10CK & $\begin{array}{l}33.36 \pm \\
2.50 \mathrm{~b}\end{array}$ & $\begin{array}{l}2.08 \pm \\
0.12 \mathrm{ab}\end{array}$ & $\begin{array}{l}4.27 \pm \\
0.21 b\end{array}$ & $\begin{array}{l}2.53 \pm \\
0.40 \mathrm{~b}\end{array}$ & $\begin{array}{l}1.53 \pm \\
0.16 a\end{array}$ & $\begin{array}{l}4.55 \pm \\
0.61 b\end{array}$ \\
\hline $\mathrm{C} 10 \mathrm{CM}$ & $\begin{array}{l}40.85 \pm \\
0.92 a\end{array}$ & $\begin{array}{l}2.67 \pm \\
0.45 a\end{array}$ & $\begin{array}{l}5.58 \pm \\
0.83 a\end{array}$ & $\begin{array}{l}3.86 \pm \\
0.50 \mathrm{a}\end{array}$ & $\begin{array}{l}1.65 \pm \\
0.28 a\end{array}$ & $\begin{array}{l}5.26 \pm \\
0.53 a\end{array}$ \\
\hline C10FM & $\begin{array}{l}37.83 \pm \\
2.25 \mathrm{a}\end{array}$ & $\begin{array}{l}1.73 \pm \\
0.50 \mathrm{~b}\end{array}$ & $\begin{array}{l}4.86 \pm \\
0.28 \mathrm{ab}\end{array}$ & $\begin{array}{l}2.03 \pm \\
0.28 b\end{array}$ & $\begin{array}{l}1.38 \pm \\
0.09 a\end{array}$ & $\begin{array}{l}4.20 \pm \\
0.21 \mathrm{~b}\end{array}$ \\
\hline \multicolumn{7}{|c|}{$\begin{array}{l}\text { Datas are means } \pm \text { standard deviation. Different small letters indicate significant differences at } P< \\
0.05 \text {. } C K=\text { deionized water, } C M=\text { cotton straw } D O M, F M=\text { farmyard manure } D O M ; C 0=\text { no exgenous }\end{array}$} \\
\hline
\end{tabular}




\section{The effect of DOM on Cd transportation of various parts of cotton}

Different levels of exogenous $\mathrm{Cd}$ addition have different effects on the translocation of cotton. Compared to C0CK, C5CK and C10CK reached high levels of transport coefficients, except for lower roots-stems transport coefficients, with all parts of C5CK having higher transport coefficients than C10CK.

When the DOM was applied, different changes in the transfer coefficients were produced at each site. Compared to $\mathrm{COCK}$, the roots-stems transport coefficients were significantly lower in the COCM and COFM treatments, except for the increased roots-stems transport coefficients. Compared to C5CK, the C5CM treatment showed significantly higher stems-leavess, stems-shells, stems-lints and stems-seeds transport coefficients and lower roots-stems transport coefficients, while the C5FM treatment showed the opposite trend to $\mathrm{C} 5 \mathrm{CM}$. However, at the $\mathrm{C} 10$ level, the $\mathrm{CK}, \mathrm{CM}$ and $\mathrm{FM}$ treatments showed similar trends.

Table 5

The effect of DOM on Cd transportation of various parts of cotton.

\begin{tabular}{|c|c|c|c|c|c|}
\hline Treatments & $\mathrm{TF}_{\text {Roots - Stems }}$ & $\mathrm{TF}_{\text {Stems - Leaves }}$ & TF $_{\text {Stems- Shells }}$ & $\mathrm{TF}_{\text {Stems- lints }}$ & $\mathrm{TF}_{\text {Stems- Seeds }}$ \\
\hline COCK & $0.24 \pm 0.02 a$ & $0.75 \pm 0.04 a$ & $0.19 \pm 0.01 a$ & $0.23 \pm 0.02 a$ & $0.39 \pm 0.04 a$ \\
\hline $\mathrm{COCM}$ & $0.40 \pm 0.05 a$ & $0.27 \pm 0.02 b$ & $0.10 \pm 0.01 b$ & $0.13 \pm 0.03 b$ & $0.13 \pm 0.02 b$ \\
\hline COFM & $0.47 \pm 0.08 a$ & $0.32 \pm 0.04 b$ & $0.10 \pm 0.01 b$ & $0.11 \pm 0.01 b$ & $0.15 \pm 0.03 b$ \\
\hline C5CK & $0.07 \pm 0.00 \mathrm{a}$ & $2.09 \pm 0.28 b$ & $1.45 \pm 0.18 b$ & $0.96 \pm 0.15 b$ & $2.16 \pm 0.22 b$ \\
\hline C5CM & $0.03 \pm 0.00 \mathrm{~b}$ & $5.37 \pm 0.39 a$ & $2.67 \pm 0.36 a$ & $1.25 \pm 0.15 a$ & $4.62 \pm 0.31 \mathrm{a}$ \\
\hline C5FM & $0.08 \pm 0.01 a$ & $1.53 \pm 0.05 b$ & $0.96 \pm 0.01 b$ & $0.60 \pm 0.09 c$ & $2.10 \pm 0.25 b$ \\
\hline C10CK & $0.06 \pm 0.01 a$ & $2.08 \pm 0.15 a$ & $1.28 \pm 0.07 a b$ & $0.75 \pm 0.13 a$ & $2.15 \pm 0.56 a$ \\
\hline $\mathrm{C} 10 \mathrm{CM}$ & $0.06 \pm 0.01 a$ & $2.16 \pm 0.36 a$ & $1.55 \pm 0.11 a$ & $0.62 \pm 0.13 a$ & $2.22 \pm 0.33 a$ \\
\hline C10FM & $0.05 \pm 0.01 b$ & $2.90 \pm 0.66 a$ & $1.15 \pm 0.23 b$ & $0.77 \pm 0.10 \mathrm{a}$ & $2.99 \pm 0.18 a$ \\
\hline \multicolumn{6}{|c|}{$\begin{array}{l}\text { Datas are means } \pm \text { standard deviation. Different small letters indicate significant differences at } P< \\
0.05 . \mathrm{CK}=\text { deionized water, } \mathrm{CM}=\text { cotton straw } \mathrm{DOM}, \mathrm{FM}=\text { farmyard manure } \mathrm{DOM} ; \mathrm{CO}=\text { no exgenous } \\
\mathrm{Cd} \text { addition, } \mathrm{C} 5=5 \mathrm{mg} \cdot \mathrm{kg}^{-1} \text { exgenous } \mathrm{Cd} \text { addition, } \mathrm{C} 10=10 \mathrm{mg} \cdot \mathrm{kg}^{-1} \text { exgenous } \mathrm{Cd} \text { addition. }\end{array}$} \\
\hline
\end{tabular}

The first principal component accounted for $87.95 \%$ and the second principal component accounted for $2.85 \%$, with a cumulative rate of $90.80 \%$ to explain all variables (Fig. 2). The results showed that the line segments of Cd content in roots, leaves, seeds and shells were longer, indicating that Cd content in roots, leaves, seeds and shells had a greater influence on cotton physiological indicators. The Cd content of 
various organs was positively correlated with $\mathrm{Ci}, \mathrm{CAT}$ and MDA, and negatively correlated with other physiological indicators. C10CM, C10FM, C10CK, C5CM and C5FM were located in the second and third quadrants, indicating that these treatments had a greater effect on cotton Cd content and were negatively correlated. COCK, COCM, COFM and C5CK were positively correlated with cotton total biomass, SOD, and SPAD were positively correlated.

\section{Discussion}

$\mathrm{Cd}$ is a non-essential element in plant growth and when $\mathrm{Cd}^{2+}$ accumulates in plants to a certain level, it inhibits normal plant production and development (Yang et al. 2021). In this study, an increase in Cd stress concentration (C0, C5 and C10) significantly reduced plant biomass, which is similar to the results of Sala's study (Sala et al. 2021). Total cotton biomass was higher in CM and FM treatments than CK under $\mathrm{C} 0$ conditions, but decreased at C5 and C10 levels compared to CK (4.74\%-7.87\% and $0.98 \%-8.44 \%$ ), in addition CM treatment caused stronger inhibition of cotton growth by $\mathrm{Cd}$ than FM treatment. The reason for this may be that DOM as part of organic matter can improve soil nutrient availability and promote plant growth (Fachin et al. 2021). However, in the case of Cd contamination, DOM alters heavy metal bioeffectiveness due to its own structural characteristics (Hur and Lee 2011), where $\mathrm{CM}$ has more low molecular weight hydrophibic organic matter (Table 1), resulting in stronger inhibition of $\mathrm{Cd}$ on cotton biomass accumulation by $\mathrm{CM}$ treatment than FM in either $\mathrm{C} 5$ or $\mathrm{C} 10$ levels.

Photosynthesis is an important physiological process in plant growth, but Cd stress can inhibit plant photosynthesis by interfering with chlorophyll synthesis and causing chloroplast degradation (Yang et al. 2021). In this study, the increase in Cd concentration decreased leaves SPAD values and net photosynthetic rate, which is the same as the results of Liu's study (Liu et al. 2021). The addition of DOM at the $C 0$ level increased the SPAD value and photosynthetic intensity of leaves, probably explained by the fact that DOM application increased the nutrient uptake capacity of the roots system, promoted chloroplast synthesis and thus increased photosynthetic intensity. However, the addition of DOM at C5 and C10 levels showed an inhibitory effect, which may be due to the fact that DOM application increased the contact area between roots and soil nutrients while increasing the contact area between roots and $\mathrm{Cd}$, and in addition DOM application also made the effectiveness of soil Cd increase (Wang et al. 2020), which increased the stress level of cotton at the same Cd level under CM and FM treatments, resulting in the blockage of chlorophyll synthesis. In addition, reactive oxygen species (ROS) produced by cells under Cd stress conditions may cause oxidative damage to organelles such as chloroplasts and mitochondria in cells leading to their inability to function properly (Wang et al. 2019), and thus photosynthesis is inhibited. Therefore, treatments with DOM applied at the same Cd level (C5 and C10) exhibited lower photosynthetic intensity and SPAD values than CK.

Under heavy metal stress, plant cells produce ROS and gradually accumulate them, damaging the cell structure and slowing down plant growth (Hassan et al. 2020). For this reason, the antioxidant system consisting of enzymes such as superoxide dismutase (SOD), peroxidase (POD) and catalase (CAT) in plants scavenges ROS to ensure normal plant growth (Shahid et al. 2014). At the same time, the 
production of ROS also increases malondialdehyde (MDA) activity, which is positively correlated with exogenous Cd stress concentration within a certain range (Rombel-Bryzek et al. 2017). In this study, leaves MDA and CAT activities increased with Cd concentration, and SOD and POD activities decreased with $\mathrm{Cd}$ concentration, indicating that cotton membrane system damage was increased and metabolically generated $\mathrm{H}_{2} \mathrm{O}_{2}$ was mainly scavenged by CAT (Wu et al. 2020). DOM application further affected antioxidant enzyme activities by increasing leaves $\mathrm{Cd}$ content, causing cotton's oxidative stress capacity was altered. Since cotton has been under Cd stress for a long time and the toxic effect of $\mathrm{Cd}$ on cotton has exceeded the regulatory capacity of the antioxidant system, the growth of cotton was inhibited.

The roots system is the main organ for Cd uptake and enrichment in plants, and roots cells conserve a large amount of $\mathrm{Cd}^{2+}$ in the roots through vesicular enrichment and cell walls adsorption, while the rest of $\mathrm{Cd}$ is transported upward through xylem by transpiration and redistributed in other organs (Lux et al. 2011). In this experiment, the treatments with DOM application showed more uptake in the roots at the same Cd levels (C0, C5 and C10). The reason for this may be, on the one hand, the greater roots biomass and the greater number of roots tips and roots hairs in the treatments with DOM application, which increased the area of roots contact with $\mathrm{Cd}$ in the soil, thus increasing the roots uptake of $\mathrm{Cd}$ (Meeinkuirt et al. 2019). On the other hand, it is due to the nature of DOM itself to bring in a large amount of low molecular organic matter (e.g. oxalic acid, citric acid, etc.) into the soil that directly affects Cd uptake by cotton roots, or the DOM presence increases the negative charge on the roots surface thus promoting Cd uptake by the roots (Christiansen et al. 2015). In particular, CM has more low-molecular hydrophibic organic matter and fulvic acid components, so it exhibited greater $\mathrm{Cd}$ uptake by cotton than FM under the same $\mathrm{Cd}$ level $\mathrm{CM}$ treatment. In addition, in this experiment, the $\mathrm{Cd}$ content in the cotton lint fraction of the treatment with DOM applied at C5 level was lower than that of CK. The reason for this may be that DOM application at this concentration increased the $\mathrm{Cd}$ content in the plant, but cotton produces more PCs and organic complexes such as GSH to sequester excess free $\mathrm{Cd}^{2+}$ in the cells and translocate it to the vesicles (Huang et al. 2021; Huang et al. 2021). However, since the lint composition is mainly cellulose, so that the $\mathrm{Cd}^{2+}$ originally in the lint is transferred to the vesicles in other parts of the lint, it showed a lower Cd content in the lint under DOM treatment. However, this effect was not significantly different at the $\mathrm{C} 10$ level. In general, the seeds had the highest $\mathrm{Cd}$ content of cotton plant reproductive organs, followed by the shells and lints (lawali 2002), which were similar to the results of the present study.

Redundancy analysis showed that Cd content in various parts was positively correlated with $\mathrm{Ci}$, CAT and $\mathrm{MDA}$, and negatively correlated with other indicators, indicating that $\mathrm{Cd}$ accumulation in various parts of cotton had an inhibitory effect on cotton growth. The treatments were closely related to cotton biomass and other indicators at the $\mathrm{CO}$ level.COCK, COCM, COFM and C5CK were located in the first and fourth quadrants, indicating that these treatments were positively correlated with cotton growth and physiological indicators and had a promoting effect on cotton growth. Liu's study also showed that the lower level of Cd concentration promoted plant growth (Liu et al. 2010). C5CM, C5FM, C10CK C10CM and 
C10FM were located in the second and third quadrants, indicating that these treatments would adversely affect cotton growth by inhibiting photosynthesis, disrupting the balance of antioxidant systems, and inhibiting biomass accumulation. In addition, $\mathrm{C} 5 \mathrm{CK}, \mathrm{C} 5 \mathrm{CM}$ and $\mathrm{C} 5 \mathrm{FM}$ were located on both sides of the PC1 axis, indicating that the inhibitory effect of the increase in Cd content in cotton due to DOM at this pollution level has been greater than its own growth-promoting effect.

\section{Conclusion}

As the level of Cd stress increased, the $\mathrm{Cd}$ content in all parts of cotton increased and cotton growth was inhibited. DOM had both promoting and inhibiting effects on cotton growth, depending on the Cd concentration in the soil, mainly in low Cd contaminated soils promoting cotton growth and increasing total dry matter accumulation, in moderate and high Cd contaminated soils ( 5 and $10 \mathrm{mg}^{\cdot \mathrm{kg}^{-1}}$ ) further inhibiting cotton photosynthesis intensity and increased membrane oxidative stress status. Moreover, cotton straw DOM had more low aromatic, low molecular hydrophibic fulvic acid fractions making it more inhibitory to cotton than farmyard manure DOM. In addition, cotton straw DOM application increased Cd content in all parts of cotton in general (except lints), whereas farmyard manure DOM application increased $\mathrm{Cd}$ content in cotton roots and stems. Therefore, we conclude that in soils with medium to high Cd contamination levels, DOM from straw and farmyard manure return resulted in $\mathrm{Cd}$ accumulation and oxidative damage in cotton, exhibiting a stronger $\mathrm{Cd}$ toxic effect reducing cotton yield but not affecting Cd concentration in cotton lints. In specific, the background values of local soil pollution should be considered when applying straw and farmyard manure to avoid adverse effects on cotton growth and yield.

\section{Declarations}

Funding This work was supported by the National Natural Science Foundation of China (No. 31660158).

Authours' contributions All authors designed the study. Tao Min, Yan Wang, and Liyang Cheng performed the experiments. Tong Luo, Lili Chen and Weidan Lu discussed the data. Sibo Ru and Junhua Li modified some experimental methods.

Data availability All data are available from the corresponding author.

\section{Compliance with ethical standards}

Ethical approval and consent to participate Not applicable.

Competing interests The authors report no competing interests.

Consent to publish All authors have read and approved the final manuscript for publication.

\section{References}


1. Akhter MF, Omelon CR, Gordon RA et al (2014) Localization and chemical speciation of cad-mium in the roots of barley and lettuce. Environ Exp Bot 100:10-19. https://doi.org/10.1016/j.envexpbot.2013.12.005

2. An MJ, Wang HJ, Fan $\mathrm{H}$ et al (2019) Effects of modifiers on the growth, photosynthesis, and antioxidant enzymes of cotton under cadmium toxicity. J Plant Growth Regul 38:1196-1205. https://doi.org/10.1007/s00344-019-09924-x

3. Chang DN, Cao WD, Bai, Js et al (2017) Effects of green manures on soil dissolved organic matter in moisture soil in North China. Spectroscopy Spectral Analysis 37(01):221-226. (in chinese) 10.3964/j.issn.1000 - 0593(2017)01-0221-06

4. Christiansen KS, Borggaard OK, Holm PE et al (2015) Experimental determinations of soil copper toxicity to lettuce (Lactuca sativa) growth in highly different copper spiked and aged soils. Environ Sci Pollut Res 22(7):5283-5292. https://doi.org/10.1007/s11356-014-3737-3

5. Fachin PA, Costa YT, Thomaz EL (2021) Evolution of the soil chemical properties in slash-and-burn agriculture along several years of fallow. Sci Total Environ 764.

https://doi.org/10.1016/j.scitotenv.2020.142823

6. Gondek K, Mierzwa-Hersztek M, Kopeć M (2018) Mobility of heavy metals in sandy soil after application of composts produced from maize straw, sewage sludge and biochar. J Environ Manag 210:87-95. https://doi.org/10.1016/j.jenvman.2018.05.034

7. Hassan MJ, Raza MA, Rehman SU et al (2020) Effect of cadmium toxicity on growth, oxidative damage, antioxidant defense system and cadmium accumulation in two sorghum cultivars. Plantsbasel 9(11):1575-1589. https://doi.org/10.3390/plants9111575

8. Hu Y, Cheng H, Tao S (2016) The challenges and solutions for cadmium-contaminated rice in china: a critical review. Environ Int 92:515-532. https://doi.org/10.1016/j.envint.2016.04.042

9. Huang HL, Li M, Rizwan M et al (2021) Synergistic effect of silicon and selenium on the alleviation of cadmium toxicity in rice plants. J Hazard Mater 401. https://doi.org/10.1016/j.jhazmat.2020.123393

10. Huang M, Li ZW, Luo NL et al (2019) Application potential of biochar in environment: insight from degradation of biochar-derived DOM and complexation of DOM with heavy metals. Sci Total Environ 646:220-228. https://doi.org/10.1016/j.scitotenv.2018.07.282

11. Huang YF, Chen JH, Zhang D et al (2021) Enhanced vacuole compartmentalization of cadmium in root cells contributes to glutathione-induced reduction of cadmium translocation from roots to shoots in pakchoi (Brassica chinensis L.). Ecotox Environ Safe 208(15). https://doi.org/10.1016/j.ecoenv.2020.111616

12. Hubova P, Tejnecky V, Ash C et al (2017) Low-molecular-mass organic acids in the forest soil environment. Mini-Rev Org Chem 14(1):75-84.

https://doi.org/10.2174/1570193X14666161130163034

13. Hur J, Lee BM (2011) Characterization of binding site heterogeneity for copper within dissolved organic matter fractions using two-dimensional correlation fluorescence spectroscopy. Chemosphere 83(11):1603-1611. https://doi.org/10.1016/j.chemosphere.2011.01.004 
14. John MK (1973) Cadmium uptake by eight food crops as influenced by various soil levels of cadmium. Environ Pollut 4:7-15. https://doi.org/10.1016/0013-9327(73)90026-8

15. Lawali D (2002) Maman Bachir. Cultivar differences in growth of cotton and their cadmium and nutrient uptake under various cadmium levels. Zhejiang University, Hangzhou

16. Liu HW, Zhang Y, Yang JS et al (2021) Quantitative source apportionment, risk assessment and distribution of heavy metals in agricultural soils from southern Shandong Peninsula of China. Sci Total Environ 767. https://doi.org/10.1016/j.scitotenv.2020.144879

17. Liu J, Liao BH, Zhou H et al (2010) Main characteristics of physiological-ecological dynamics of soybean during the growth cycle under Cd stress. Acta Ecol Sin 30(02):333-340. (in chinese)

18. Liu Y, Qi MX, Wang M et al (2021) Efffect of different exogenous selenium species application on growth and cadmium uptake of Pak Choi in cadmium cotanminated Soil. Environmental Science 42(04):2024-2030. https://doi.org/10.13227/j. hjkx. 202009017 (in chinese)

19. Lu BC, Li B, Zhan FD et al (2020) Research advance on the effect of mineralization and decomposition of green manure crops on soil cadmium availability. Journal of Agricultural Resources and Environment 1-15. (in chinese) https://doi.org/10.13254/j. jare. 2020. 0331

20. Lux A, Martinka M, Vaculik M et al (2011) Root responses to cadmium in the rhizosphere: a review. J Exp Bot 62(1):21-37. https://doi.org/10.1093/jxb/erq281

21. Meeinkuirt W, Phusantisampan T, Saengwilai $P$ (2019) Root system architecture influencing cadmium accumulation in rice (Oryza sativa L.). Int J Phytoremediat 21(1):19-26. https://doi.org/10.1080/15226514.2018.1523869

22. Meers E, Slycken SV, Adriaensen K et al (2010) The use of bio-energy crops (zea mays) for 'phytoattenuation' of heavy metals on moderately contaminated soils: a field experiment. Chemosphere 78(1):35-41. 10.1016/j.chemosphere.2009.08.015

23. Mei KC, Cheng L, Zhang Q et al (2020) Effects of dissolved organic matter from different plant sources on soil enzyme activities in subtropical forests. Chin J Plant Ecol 44(12):1273-1284. https://doi.org/10.17521/cjpe.2020.0097 (in chinese)

24. Mwilola PN, Mukumbuta I, Shitumbanuma V et al (2020) Lead, zinc and cadmium accumulation, and associated health risks, in maize grown near the kabwe mine in zambia in response to organic and inorganic soil amendments. Int J Env Res Pub He 17(23):9038-9053. https://doi.org/10.3390/ijerph17239038

25. Ni LX, Su LL, Li SY et al (2017) The characterization of dissolved organic matter extracted from different sources and their influence on cadmium uptake by Microcystis aeruginosa. Environ Toxico Chem 36(7):1856-1863. https://doi.org/10.1002/etc.3728

26. Ouariti O, Gouia H, Ghorbal MH (1997) Responses of bean and tomato plants to cadmium: growth mineral nutrition and nitrate reduction. Plant Physiol Bioch 35(5):347-354. https://doi.org/10.1104/pp.114.1.345

27. Pan Y, Zhou LX (2007) Dynamics of dissolved organic matter and its effect on copper and cadmium activity in the contaminated wheat soil: Field Micro-Plot Trials. Environmental Science 28(04):4859- 
4865. https://doi.org/10.13227/j.hjkx.2007.04.029 (in chinese)

28. Ran HZ, Guo ZH, Yi LW et al (2021) Pollution characteristics and source identification of soil metal(loid)s at an abandoned arsenic-containing mine, China. J Hazard Mater 413. https://doi.org/10.1016/j.jhazmat.2021.125382

29. Rombel-Bryzek A, Rajfur M, Zhuk O (2017) The impact of copper ions on oxidative stress in garden cress lepidium sativum. Ecol Chem Eng S 24(4):627-636. https://doi.org/10.1515/eces-2017-0041

30. Sala HR, Sukert DS, Vieira WD et al (2021) Different cadmium levels alter growth and antioxidant defense response in Cedrela fissilis and Colubrina glandulosa Flora 276. https://doi.org/10.1016/j.flora.2021.151765

31. Shahid M, Pourrut B, Dumat C et al (2014) Heavy-metal-induced reactive oxygen species: phytotoxicity and physicochemical changes in plants. Rev Environ Contam T 232:1-44. https://doi.org/10.1007/978-3-319-06746-9_1

32. Shan G, Xu J, Jiang Z et al (2019) The transformation of different dissolved organic matter subfractions and distribution of heavy metals during food waste and sugarcane leaves cocomposting. Waste Manage 87:636-644. https://doi.org/10.1016/j.wasman.2019.03.005

33. Trevisan S, Francioso O, Quaggiotti S et al (2010) Humic substances biological activity at the plantsoil interface: from environmental aspects to molecular factors. Plant Signal Behav 5(6):635-643. https://doi.org/10.4161/psb.5.6.11211

34. Wang PC, Peng H, Liu JL et al (2020) Effects of exogenous dissolved organic matter on the adsorption-desorption behaviors and bioavailabilities of $\mathrm{Cd}$ and $\mathrm{Hg}$ in a plant-soil system. Sci Total Environ 728. https://doi.org/10.1016/j.scitotenv.2020.138252

35. Wang YY, Wang Y, Li GZ, Hao L (2019) Salicylic acid-altering Arabidopsis plant response to cadmium exposure: Underlying mechanisms affecting antioxidation and photosynthesis-related processes. Ecotox Environ Safe 169:645-653. https://doi.org/10.1016/j.ecoenv.2018.11.062

36. Wu ZC, Jiang Q, Yan T et al (2020) Ammonium nutrition mitigates cadmium toxicity in rice (Oryza sativa $L$.) through improving antioxidase system and the glutathione-ascorbate cycle efficiency. Ecotox Environ Safe 189. https://doi.org/10.1016/j.ecoenv.2019.110010

37. Xie L, Yang H, Qu XX et al (2013) Characterization of water extractable organic matters from the dominant plants in Lake Dianchi by multiple spectroscopic techniques. Res Environ Sci 26(1):72-79. https://doi.org/10.13198/j.res.2013.01.76.xiel.004 (in chinese)

38. Xu LJ, Yuan Z (2009) Effect of exogenous cadmium pollution and dissolved organic matter on forms of Cd in soil. Chin J Soil Sci 40(06):1442-1445. (in chinese)

39. Yang Q, Yang C, Yu H et al (2020) The addition of degradable chelating agents enhances maize phytoremediation efficiency in cd-contaminated soils. Chemosphere 269. https://doi.org/10.1016/j.chemosphere.2020.129373

40. Yang SL, Zhang J, Chen LH (2021) Growth and physiological responses of Pennisetum sp. to cadmium stress under three different soils. Environ Sci Pollut Res 28(12):1-15. https://doi.org/10.1007/s11356-020-11701-3 
41. Yuan DH, Guo XJ, Wen L et al (2015) Detection of copper (II) and cadmium (II) binding to dissolved organic matter from macrophyte decomposition by fluorescence excitation-emission matrix spectra combined with parallel factor analysis. Environ Pollut 204:152-160.

https://doi.org/10.1016/j.envpol.2015.04.030

42. Zhang MQ, Shi AP, Ajmal M et al (2021) Comprehensive review on agricultural waste utilization and high-temperature fermentation and composting. Biomass Convers Bior 1-24.

https://doi.org/10.1007/s13399-021-01438-5

43. Zhou WJ, Ren LW, Zhu LZ (2017) Reducement of cadmium adsorption on clay minerals by the presence of dissolved organic matter from animal manure. Environ Pollut 223:247-254. https://doi.org/10.1016/j.envpol.2017.01.019

\section{Figures}
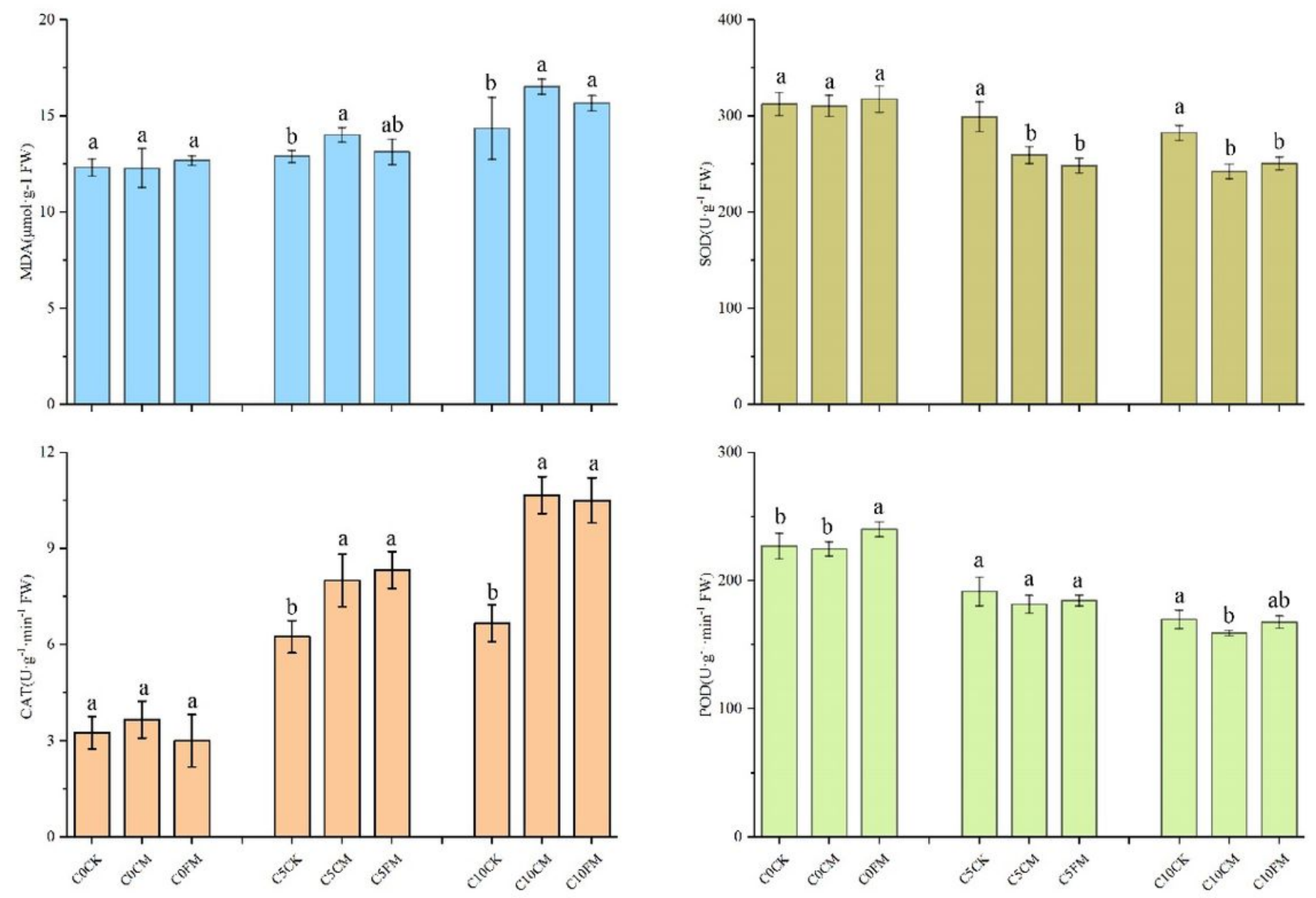

\section{Figure 1}

The effect of DOM on activities of antioxidant enzymes and MDA content of cotton leaves. Datas are means \pm standard deviation. Different small letters indicate significant differences at $P<0.05$. $C K=$ 
deionized water, $\mathrm{CM}$ = cotton straw DOM, FM = farmyard manure DOM; $\mathrm{CO}$ = no exgenous $\mathrm{Cd}$ addition, $\mathrm{C5}$ = $5 \mathrm{mg} \cdot \mathrm{kg}-1$ exgenous $\mathrm{Cd}$ addition, $\mathrm{C} 10=10 \mathrm{mg} \cdot \mathrm{kg}-1$ exgenous $\mathrm{Cd}$ addition.

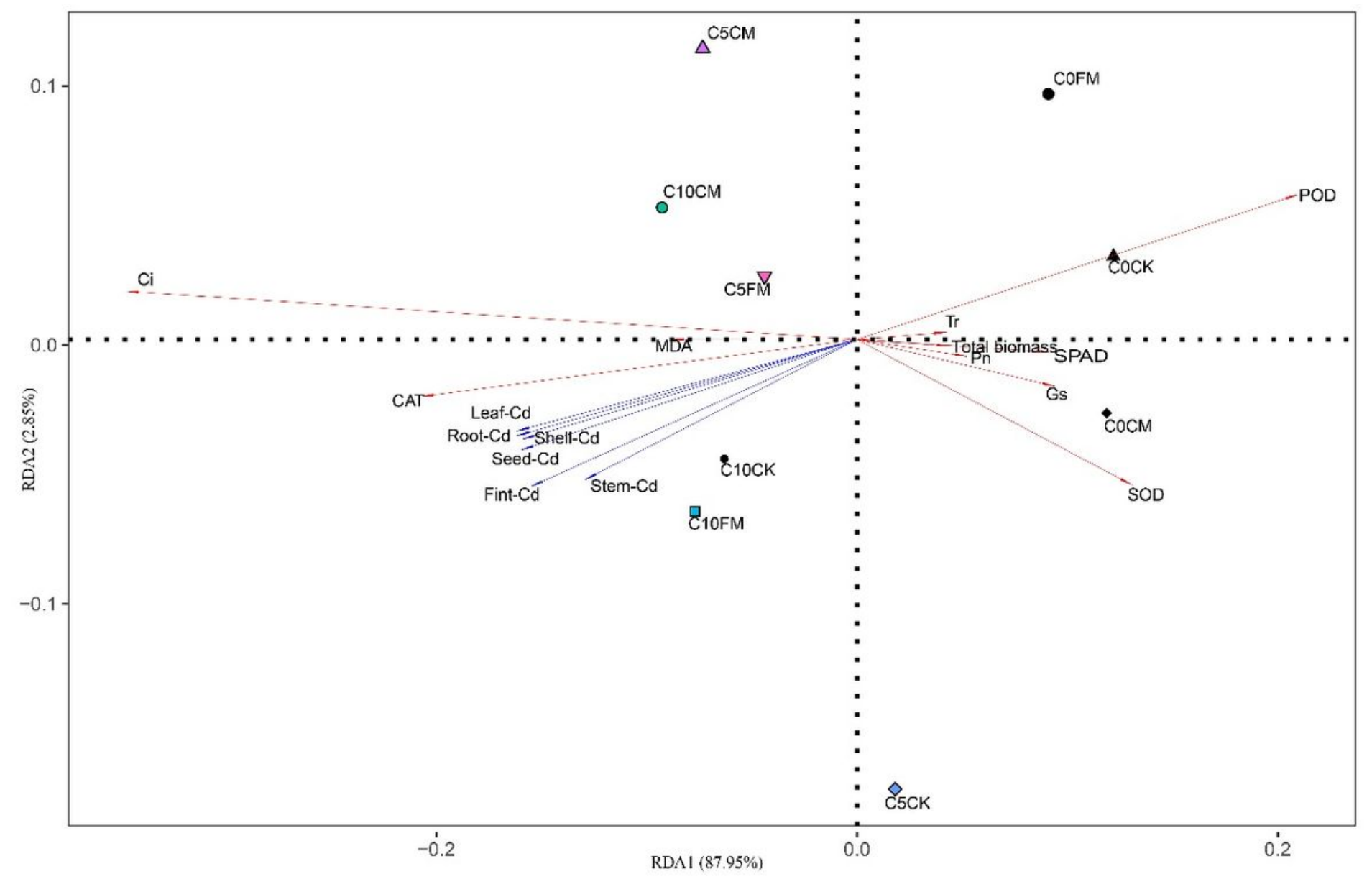

Figure 2

Redundancy analysis of $\mathrm{Cd}$ content and physiological indicators in cotton. $\mathrm{CK}=$ deionized water, $\mathrm{CM}=$ cotton straw DOM, FM = farmyard manure DOM; $\mathrm{CO}=$ no exgenous $\mathrm{Cd}$ addition, $\mathrm{C} 5=5 \mathrm{mg} \cdot \mathrm{kg}-1$ exgenous Cd addition, $\mathrm{C} 10=10 \mathrm{mg} \cdot \mathrm{kg}-1$ exgenous $\mathrm{Cd}$ addition. 